\title{
Are There Undiagnosed TBE-, Herpes- or Enteroviral Infections among Children Being Evaluated for Lyme Neuroborreliosis?
}

\author{
Barbro H. Skogman, Pia Forsberg, Sirkka Vene, Britt Akerlind \\ Center for Clinical Research, Falun, Sweden \\ Email: barbro.hedinskogman@Itdalarna.se, pia.forsberg@liu.se, sirkka.vene@smi.se, britt.akerlind@lio.se
}

Received 1 June 2014; revised 1 July 2014; accepted 1 August 2014

Copyright (C) 2014 by authors and Scientific Research Publishing Inc.

This work is licensed under the Creative Commons Attribution International License (CC BY).

http://creativecommons.org/licenses/by/4.0/

(c) (i) Open Access

\begin{abstract}
Lyme neuroborreliosis (LNB) in children is a challenging diagnosis based on clinical manifestations and laboratory findings. The aim of this study was to investigate whether herpes simplex virus (HSV) 1 or 2, varicella zoster virus (VZV), enterovirus or tick-borne encephalitis virus (TBEV) could be identified in cerebrospinal fluid (CSF) or serum from children being evaluated for LNB, in order to elucidate whether such infectious diseases may be missed by the clinician. Methods: Ninety-nine pediatric patients $(n=99)$ were retrospectively included from a previous study on LNB in southeast of Sweden. They had been diagnosed as "Possible LNB" or "Not determined" due to negative Borrelia antibody index in CSF. Routine polymerase chain reaction (PCR) methods were used for detection of herpes viral RNA or enteroviral DNA in CSF. An ELISA assay was used for detection of anti-TBEV antibodies (IgM and IgG) in serum. Results: One patient showed elevated anti-TBEV IgM and IgG antibodies in serum, indicating a current TBE infection. No positive PCR reactions for HSV 1 or 2, VZV or enterovirus were detected in CSF from any of the patients. In conclusion, our results suggest that undiagnosed herpes- or enteroviral infections are unlikely to explain CNS symptoms in children being evaluated for LNB, whereas missed TBE infections may occur. TBEV serology should be included when evaluating children for LNB in TBE endemic areas.
\end{abstract}

\section{Keywords}

Enterovirus, Herpes Simplex Virus, Lyme Neuroborreliosis, Varicella Zoster Virus, Tick-Borne Encephalitis

\section{Introduction}

Lyme Borreliosis (LB) is caused by the spirochete Borrelia burgdorferi and is the most common tick-borne in-

How to cite this paper: Skogman, B.H., Forsberg, P., Vene, S. and Akerlind, B. (2014) Are There Undiagnosed TBE-, Herpesor Enteroviral Infections among Children Being Evaluated for Lyme Neuroborreliosis? Open Journal of Clinical Diagnostics, 4, 123-129. http://dx.doi.org/10.4236/ojcd.2014.43020 
fection in both Europe and the USA [1] [2]. The infection may give rise to different symptoms by affecting organs such as the skin, joints, heart muscle or nervous system [3]-[5]. Neurological signs and symptoms are not specific and the diagnosis Lyme Neuroborreliosis (LNB) needs laboratory confirmation [6] [7]. According to European guidelines, both pleocytosis in CSF $\left(>5 \times 10^{6}\right.$ mononuclear cells $\left./ \mathrm{L}\right)$ and intrathecally produced Borrelia specific antibodies (i.e. positive antibody index, AI) are needed to confirm the LNB diagnosis [7]. Among children with neurological symptoms suggestive for LNB, many cases do not meet these criteria for confirmed LNB [8]-[11]. Patients may receive antibiotic treatment on vague grounds and investigation for other neurotropic agents are seldom performed unless the patient show specific manifestations of viral infection such as skin rash, vesicles, diarrea or distinct signs of viral meningitis/encephalitis.

Acute facial nerve palsy or subacute meningitis are major neurological manifestations in LNB [12] [13]. However, facial nerve palsy may also be associated with viral infection, such as an acute or reactivated herpes simplex virus (HSV) infection or a reactivated varicella zoster virus (VZV), even when detectable vesicles or other clinical manifestations of viral infection are absent [14]-[18]. Antiviral therapy and/or corticosteroids have been shown to improve the prognosis in adult patients with idiopathic facial nerve palsy [19], but studies in children are few and not conclusive [20] [21]. As for children with meningeal signs and symptoms, clinical manifestations associated with enteroviral infection are not always easily distinguishable from LNB and the distribution of season is similar [22]. Furthermore, tick-borne encephalitis (TBE) is a tick-borne infectious disease that peaks during summer season with clinical features that may mimic LNB and may be unspecific in smaller children [4] [23]-[25]. For these reasons, TBE-, herpes- and enteroviral infections may be deceptive for the clinician.

The aim of this study was to investigate whether HSV 1 or 2, VZV, enterovirus or TBEV could be identified in CSF or serum from children being evaluated for LNB, in order to elucidate whether such infectious diseases may be missed by the clinician.

\section{Material and Methods}

\subsection{Study Population}

Children with neurological symptoms suggestive for LNB were subjects in this retrospective study from a high endemic area in southeast Sweden. Patients had taken part in a previous prospective study on LNB and had been diagnosed as "Confirmed LNB", "Possible LNB" or "Not determined" based on laboratory findings [9]. Out of 177 consecutive patients, 72 children had been diagnosed as "Confirmed LNB" with pleocytosis in CSF and intrathecally produced Borrelia specific antibodies in CSF (positive AI), following the European case definition [6] [7]. These patients were not included in our present study since the aim was to focus on children not meeting the criteria for "Confirmed LNB". Furthermore, 6 children had to be excluded due to missing clinical data $(\mathrm{n}=1)$, insufficient patient samples $(\mathrm{n}=3)$ or other diagnosis such as demyelisation disease $(\mathrm{n}=1)$ and sarcoidosis $(\mathrm{n}=$ 1). These excluded patients $(n=6)$ did not differ in age or gender compared to the study population $(n=99)$. Children with distinct symptoms of aseptic meningitis were not included.

Thus, 99 children were enrolled in our retrospective study. Out of these children, 44 patients had been diagnosed as "Possible LNB" with pleocytosis in CSF but no Borrelia specific antibodies in CSF (negative AI). Furthermore, 55 patients with no pleocytosis in CSF and no Borrelia antibodies in CSF (negative AI) had been diagnosed as "Not determined".

Demographic and clinical characteristics of the study population are shown in Table 1. No patient had had any skin rash, vesicles, diarrhea or distinct signs of viral meningitis/encephalitis at admission. None of the patients in the study had been treated for a previous LNB. Data on TBE vaccination status was unfortunately not available.

\subsection{Laboratory Assays}

For Borrelia diagnostics, a flagella-based ELISA assay was used to detect Borrelia specific anti-IgM and anti-IgG antibodies in serum and CSF (DAKO, Glostrup, Denmark) [26] [27]. Cut-off levels in serum were set as recommended by the manufacturer. In CSF, an antibody index (AI) based upon the optical density (OD) formula was calculated, as recommended, to ensure measure of intrathecal antibody production. $\mathrm{OD}_{\mathrm{CSF}} / \mathrm{OD}_{\text {serum }} \times$ $\left(\mathrm{OD}_{\mathrm{CSF}}-\mathrm{OD}_{\text {serum }}\right)$. The test was considered positive when the $\mathrm{AI}$ was $\geq 0.3$ [27]. Immunoblot was not used as confirmatory test for LNB. 
Table 1. Demographic and clinical characteristics of patients $(n=99)$.

\begin{tabular}{|c|c|c|}
\hline & $\begin{array}{c}\text { "Possible LNB" } \\
(\mathrm{n}=44)\end{array}$ & $\begin{array}{c}\text { "Not determined" } \\
(\mathrm{n}=55)\end{array}$ \\
\hline Age, years, median (range) & $7(1-18)$ & $12(2-18)$ \\
\hline Male, n (\%) & $20(45)$ & $26(47)$ \\
\hline Known tick bite, n (\%) & $26(59)$ & $31(56)$ \\
\hline \multicolumn{3}{|l|}{ Duration of symptoms, n (\%) } \\
\hline$<1$ week & $26(59)$ & $21(38)$ \\
\hline 1 - 4 weeks & $16(36)$ & $15(27)$ \\
\hline 1 - 2 months & $2(5)$ & $8(15)$ \\
\hline$>2$ months & $0(0)$ & $11(20)$ \\
\hline \multicolumn{3}{|l|}{ Major clinical manifestations, $\mathrm{n}(\%)^{\mathrm{a}}$} \\
\hline Facial nerve palsy & $34(77)$ & $20(36)$ \\
\hline Headache & $26(59)$ & $40(73)$ \\
\hline Meningitis, subacute & $20(45)$ & $6(11)$ \\
\hline EM and/or lymfocytoma & $23(52)$ & $3(5)$ \\
\hline \multicolumn{3}{|l|}{ Laboratory findings, n (\%) } \\
\hline Pleocytosis in CSF, median (range) ${ }^{\mathrm{b}}$ & $68(5-575)$ & $1(0-4)$ \\
\hline Anti-Borrelia antibodies in CSF, $\mathrm{n}(\%)^{\mathrm{c}}$ & $0(0)$ & $0(0)$ \\
\hline \multicolumn{3}{|l|}{ Anti-Borrelia antibodies in serum, $\mathrm{n}(\%)^{\mathrm{d}}$} \\
\hline Anti-IgM & $12(27)$ & $6(11)$ \\
\hline Anti-IgG & $3(7)$ & $2(4)$ \\
\hline Anti-IgM and IgG & $9(20)$ & $6(11)$ \\
\hline \multicolumn{3}{|l|}{ Antibiotic treatment, n (\%) } \\
\hline Ceftriaxone, iv & $21(48)$ & $0(0)$ \\
\hline Doxycycline, po & $23(52)$ & $3(5)$ \\
\hline
\end{tabular}

${ }^{\mathrm{a}}$ Patients may have several clinical manifestations. ${ }^{\mathrm{b}}$ Pleocytosis: $>5 \times 10^{6}$ mononuclear cells $/ \mathrm{L}$ in CSF. ${ }^{\mathrm{C}}$ Intrathecally produced Borrelia specific IgG or IgM antibodies. ${ }^{\mathrm{d}}$ Elevated anti-Borrelia antibody titers in serum, as recommended by the manufacturer. LNB = Lyme Neuroborreliosis, CSF = cerebrospinal fluid, EM = erythema migrans, $\mathrm{Ig}=$ immunoglobulin, iv = intravenous, po = peroral.

A commercial routine ELISA assay (Immunozym kit, Germany) was used on serum samples for TBEV serology [28] [29]. Anti-IgM antibodies for detection of a current TBE infection and anti-IgG antibodies for detection of a previous TBE infection or vaccination. Cut-off levels were set as recommended by the manufacturers. If anti-TBEV antibody titers were elevated, a neutralization test was conducted to confirm the TBE diagnosis [30].

For viral PCR investigations, a commercial total nucleic acid kit was used for the extraction of viral deoxyribonucleic acid (DNA) or ribonucleic acid (RNA) from CSF samples (Roche MagnaPure Compact instrument). HSV 1 and 2 and VZV were analysed in a routine real-time PCR whereas enteroviral analyses were carried out with a routine semi-nested PCR [31]-[33]. All serum and CSF samples had been frozen and stored at $-70^{\circ} \mathrm{C}$ for 2 - 4 years before viral analyses were performed.

\subsection{Statistical Analyses}

SPSS soft wear, version 15.0, was used for statistical calculations. Mann Whitney U test and Fishers exact test 
were used when comparing demographic data between excluded $(n=6)$ and included $(n=99)$ patients. Levels of significance were determined as $\mathrm{p}<0.05$. Written informed consent was obtained from all children and parents/guardians-The study was approved by the regional Ethical Committee at Linköping University (Dnr 03546)

\section{Results}

One patient was identified with elevated anti-TBEV IgM and IgG antibody titers in serum, indicating a current TBE infection (Table 2). This patient was a 17-year-old girl who had reported headache, fatigue, fever and loss of appetite with duration of $2-4$ weeks. She showed no abnormalities in neurological examination. The lumbar puncture at admission showed mononuclear pleocytosis in CSF $\left(24 \times 10^{6}\right.$ mononuclear cells/L). Initially, she received antibiotic treatment due to a suspected LNB but investigation showed no Borrelia specific antibodies in serum or CSF (negative AI). She recovered gradually but reported persistent headache at 6-month follow-up. The confirmatory TBEV neutralization test was negative and follow-up serology was unfortunately not available. Thus, a current TBE infection was highly suspected but not confirmed in this patient. Furthermore, 10 patients had elevated anti-TBEV IgG antibody titers, indicating a previous TBE infection or vaccination. No patient was anti-IgM antibody positive alone.

No positive PCR reactions for HSV 1 or 2, VZV or enterovirus were detected in CSF samples from any of the patients in the study (Table 2).

\section{Discussion}

In this retrospective study of children being evaluated for LNB, one patient with a highly suspected current TBE infection was identified whereas no indications of HSV 1 or 2, VZV or enteroviral infections were found by PCR analyses in CSF. These negative PCR findings may possibly raise questions about the reliability of the PCR methods. However, all CSF samples were run together with routine samples at the laboratory, including accurate positive and negative controls, assuring a high reliability. Handling and storage of samples has been correct and the amount of CSF in each patient sample has been sufficient $(0.5 \mathrm{~mL})$.

It is known that herpes viral RNA or DNA may be difficult to detect in CSF in the earliest phase of an acute facial nerve palsy as well as when viral re-activation occurs [34]. However, the duration of symptoms among patients in our study was not extremely short (median 1, 5 weeks) and negative results should probably not be explained by very short durations of symptoms. Re-activation of a viral infection is generally less likely in children than in adults. Furthermore, no patient in the study had vesicles or clinical manifestations of a current herpes viral infection. In this aspect, we are therefore prone to believe that our negative results on viral PCR are reliable. However, a number of patients had a rather long duration of symptoms and the virus might already have been cleared from CSF, which would explain the negative CSF findings. In such cases, neurological symptoms should be looked upon as sequelae after CNS infection.

Table 2. Viral investigations in serum and CSF.

\begin{tabular}{lcc} 
& $\begin{array}{c}\text { "Possible LNB” } \\
\mathrm{n}=44 \\
\mathrm{n}(\%)\end{array}$ & $\begin{array}{c}\text { Not determined” } \\
\mathrm{n}=55 \\
\mathrm{n}(\%)\end{array}$ \\
\hline $\begin{array}{l}\text { Anti-TBEV antibodies in serum }{ }^{\mathrm{a}} \\
\text { Anti-IgM }\end{array}$ & $0(0)$ & $0(0)$ \\
Anti-IgG & $4(9)$ & $6(11)$ \\
Anti-IgG and IgM & $1(2)$ & $0(0)$ \\
Herpes simplex virus 1 or $2^{\mathrm{b}}$ & $0(0)$ & $0(0)$ \\
Varicella zoster virus $^{\mathrm{b}}$ & $0(0)$ & $0(0)$ \\
Enterovirus $^{\mathrm{b}}$ & $0(0)$ & $0(0)$ \\
\hline
\end{tabular}

${ }^{\mathrm{a}}$ Detected as elevated anti-TBEV antibodies in serum. ${ }^{\mathrm{b}}$ Detected by PCR in CSF. CSF = cerebrospinal fluid, TBEV = tick-borne encephalitis virus, Ig = Immunoglobulin, PCR = polymerase chain reaction. 
Admittedly, a study designed for investigation of viral etiology should have included antibody evaluation of serum and CSF in parallel and as repeated samples over time, in addition to PCR detection in CSF. This could not be provided in our retrospective setting, nor were there fecal samples available for enteroviral isolation. In addition, due to ethical reasons, repeated lumbar punctures are rarely performed in young patients.

Furthermore, some of the patients might have been infected by neurotropic agents not tested for in our present study, i.e. Epstein-Barr virus (EBV), human herpes virus (HHV) 6 or 7, cytomegal virus (CMV), mycoplasma or influenza A or B [18]. Different refined method for detection of different causative agents in the central nervous system (CNS) has been in focus by Huttunen et al. [35]. A wide spectrum of analyses was used and a microbiological diagnosis was obtained in up to $85 \%$ of pediatric CNS infection. However, these patients all presented with distinct signs and symptoms of acute meningitis and/or encephalitis and are in this aspect not comparable to children in our study. In addition, the authors comment on the high costs of their extensive diagnostic approach and that hopefully future multi-array method may reduce the overall expense for such extensive evaluations.

Among children in our study with pleocytosis in CSF, all showed a clear dominance of mononuclear cells in CSF ( $>90 \%$ of the total white cell count). According to previous studies on LNB versus viral meningitis, mononuclear pleocytosis in CSF has been strongly predictive for LNB rather than viral meningitis and consequently, these patients are most probably early LNB patients [22] [36]. This is also in line with the negative PCR findings for enterovirus in CSF in our study. Furthermore, an interesting analysis of clinical features and etiology of CNS infections has been published by Waespe et al. [37]. They report that among children with acute facial nerve palsy and/or meningitis in combination with mononuclear pleocytosis in CSF, the most common etiology was LNB.

Some children had EM/lymfocytoma and/or Borrelia antibodies in serum in the group "Not determined" (Table 1), suggesting they may have a current LB (i.e. EM and headache), an early LNB (i.e. facial nerve palsy without pleocytosis) or a previous asymptomatic LB (anti-flagella IgG in serum). Some patients just had a low anti-flagella IgM response in serum indicating an unspecific cross reactivity. A few patients received antibiotic treatment on vague grounds (Table 1). There were also a few children with facial nerve palsy and/or headache who had no pleocytosis in CSF, no EM, no anti-Borrelia antibodies in serum and obviously, according to our results, no clinical or laboratory evidence of TBE-, herpes- or enteroviral infection. They should accordingly be classified as acute idiopathic Bell's palsy or unspecific headache.

The one patient with highly suspected current TBE infection (both anti-IgM and IgG antibodies in serum) showed unspecific symptoms and no neurological abnormalities, making her extra interesting as an example of how TBE infections may be deceptive for the clinician. However, one should keep in mind that anti-IgM antibodies in serum are essential for the TBE diagnosis whereas anti-IgG antibodies alone are a merely a measure of the seroprevalence or TBE vaccination coverage in the region.

\section{Conclusion}

In conclusion, our results suggest that undiagnosed herpes- or enteroviral infections are unlikely to explain CNS symptoms in children being evaluated for LNB, whereas missed TBE infections may occur. TBEV serology should be included when evaluating children for LNB in TBE endemic areas.

\section{Acknowledgements}

Special thanks to Bengt-Göran Hansson and the staff at the Department of Microbiology in Malmö for organizing and running the PCR-based analyses and to the staff at the Swedish Institute for Infectious Disease Control in Stockholm for running the TBEV serology.

The study was funded by the Research Council in Southeast Sweden (FORSS), the County Council in Östergötland, the Center of Clinical Research in Dalarna (CKF), the Swedish Society of Medicine, the Holmia Foundation, The Samariten Foundation and the Lions Foundation.

\section{Conflict of Interest}

The authors declare that they have no conflict of interest.

\section{References}

[1] Stanek, G. and Strle, F. (2003) Lyme Borreliosis. The Lancet, 362, 1639-1647. 
http://dx.doi.org/10.1016/S0140-6736(03)14798-8

[2] Steere, A.C. (2006) Lyme Borreliosis in 2005, 30 Years after Initial Observations in Lyme Connecticut. Wiener klinische Wochenschrift, 118, 625-633. http://dx.doi.org/10.1007/s00508-006-0687-x

[3] Strle, F. and Stanek, G. (2009) Clinical Manifestations and Diagnosis of Lyme Borreliosis. Current Problems in Dermatology, 37, 51-110. http://dx.doi.org/10.1159/000213070

[4] Bryant, K.A. and Marshall, G.S. (2000) Clinical Manifestations of Tick-Borne Infections in Children. Clinical and Diagnostic Laboratory Immunology, 7, 523-527.

[5] Shapiro, E.D. and Gerber, M.A. (2000) Lyme Disease. Clinical Infectious Diseases, 31, 533-542. http://dx.doi.org/10.1086/313982

[6] Stanek, G., et al. (1996) European Union Concerted Action on Risk Assessment in Lyme Borreliosis: Clinical Case Definitions for Lyme Borreliosis. Wiener klinische Wochenschrift, 108, 741-747.

[7] Mygland, A., et al. (2010) EFNS Guidelines on the Diagnosis and Management of European Lyme Neuroborreliosis. European Journal of Neurology, 17, 8-16, e1-4.

[8] Sood, S.K. (2006) What We Have Learned about Lyme Borreliosis from Studies in Children. Wiener klinische Wochenschrift, 118, 638-642. http://dx.doi.org/10.1007/s00508-006-0689-8

[9] Skogman, B.H., et al. (2008) Lyme Neuroborreliosis in Children: A Prospective Study of Clinical Features, Prognosis, and Outcome. Pediatric Infectious Disease Journal, 27, 1089-1094. http://dx.doi.org/10.1097/INF.0b013e31817fd423

[10] Tveitnes, D., Oymar, K. and Natas, O. (2009) Laboratory Data in Children with Lyme Neuroborreliosis, Relation to Clinical Presentation and Duration of Symptoms. Scandinavian Journal of Infectious Diseases, 41, 355-362. http://dx.doi.org/10.1080/00365540902787666

[11] Oymar, K. and Tveitnes, D. (2009) Clinical Characteristics of Childhood Lyme Neuroborreliosis in an Endemic Area of Northern Europe. Scandinavian Journal of Infectious Diseases, 41, 88-94. http://dx.doi.org/10.1080/00365540802593453

[12] Christen, H.J., et al. (1993) Epidemiology and Clinical Manifestations of Lyme Borreliosis in Childhood. A Prospective Multicentre Study with Special Regard to Neuroborreliosis. Acta Paediatrica, 386, 1-75. http://dx.doi.org/10.1111/j.1651-2227.1993.tb18082.x

[13] Tveitnes, D., et al. (2012) Lyme Meningitis, the Major Cause of Childhood Meningitis in an Endemic Area: A Population Based Study. Archives of Disease in Childhood, 97, 215-220. http://dx.doi.org/10.1136/archdischild-2011-300526

[14] Khine, H., et al. (2008) Association between Herpes Simplex Virus-1 Infection and Idiopathic Unilateral Facial Paralysis in Children and Adolescents. The Pediatric Infectious Disease Journal, 27, 468-469. http://dx.doi.org/10.1097/INF.0b013e31816507c3

[15] Furuta, Y., et al. (1998) Reactivation of Herpes Simplex Virus Type 1 in Patients with Bell's Palsy. Journal of Medical Virology, 54, 162-166. http://dx.doi.org/10.1002/(SICI)1096-9071(199803)54:3<162::AID-JMV3>3.0.CO;2-3

[16] Furuta, Y., et al. (2005) Varicella-Zoster Virus Reactivation Is an Important Cause of Acute Peripheral Facial Paralysis in Children. The Pediatric Infectious Disease Journal, 24, 97-101. http://dx.doi.org/10.1097/01.inf.0000151032.16639.9c

[17] Furuta, Y., et al. (2001) Herpes Simplex Virus Type 1 Reactivation and Antiviral Therapy in Patients with Acute Peripheral Facial Palsy. Auris Nasus Larynx, 28, S13-S17. http://dx.doi.org/10.1016/S0385-8146(00)00105-X

[18] Kanerva, M., et al. (2013) Microbiologic Findings in Acute Facial Palsy in Children. Otology \& Neurotology, 34, 8287. http://dx.doi.org/10.1097/MAO.0b013e318289844c

[19] Engstrom, M., et al. (2008) Prednisolone and Valaciclovir in Bell’s Palsy: A Randomised, Double-Blind, Placebo-Controlled, Multicentre Trial. The Lancet Neurology, 7, 993-1000. http://dx.doi.org/10.1016/S1474-4422(08)70221-7

[20] Unuvar, E., et al. (1999) Corticosteroid Treatment of Childhood Bell’s Palsy. Pediatric Neurology, 21, 814-816. http://dx.doi.org/10.1016/S0887-8994(99)00099-5

[21] Pitaro, J., Waissbluth, S. and Daniel, S.J. (2012) Do Children with Bell's Palsy Benefit from Steroid Treatment? A Systematic Review. International Journal of Pediatric Otorhinolaryngology, 76, 921-926. http://dx.doi.org/10.1016/j.ijporl.2012.02.044

[22] Shah, S.S., et al. (2005) Early Differentiation of Lyme from Enteroviral Meningitis. The Pediatric Infectious Disease Journal, 24, 542-545. http://dx.doi.org/10.1097/01.inf.0000164767.73746.6e

[23] Arnez, M., et al. (2003) Etiology of Tick-Borne Febrile Illnesses in Slovenian Children. Annals of the New York Academy of Sciences, 990, 353-354. http://dx.doi.org/10.1111/j.1749-6632.2003.tb07388.x

[24] Lesnicar, G., et al. (2003) Pediatric Tick-Borne Encephalitis in 371 Cases from an Endemic Region in Slovenia, 1959 
to 2000. The Pediatric Infectious Disease Journal, 22, 612-617. http://dx.doi.org/10.1097/00006454-200307000-00009

[25] Sundin, M., et al. (2012) Pediatric Tick-Borne Infections of the Central Nervous System in an Endemic Region of Sweden: A Prospective Evaluation of Clinical Manifestations. European Journal of Pediatrics, 171, 347-352. http://dx.doi.org/10.1007/s00431-011-1542-2

[26] Hansen, K., Pii, K. and Lebech, A.M. (1991) Improved Immunoglobulin M Serodiagnosis in Lyme Borreliosis by Using a Mu-Capture Enzyme-Linked Immunosorbent Assay with Biotinylated Borrelia burgdorferi Flagella. Journal of Clinical Microbiology, 29, 166-173.

[27] Hansen, K. and Lebech, A.M. (1991) Lyme Neuroborreliosis: A New Sensitive Diagnostic Assay for Intrathecal Synthesis of Borrelia burgdorferi-Specific Immunoglobulin G, A, and M. Annals of Neurology, 30, 197-205. http://dx.doi.org/10.1002/ana.410300212

[28] Treib, J., et al. (1998) Prevalence of Antibodies to Tick-Borne Encephalitis Virus and Borrelia burgdorferi Sensu Lato in Samples from Patients with Abnormalities in the Cerebrospinal Fluid. Zentralblatt für Bakteriologie, 288, 253-266. http://dx.doi.org/10.1016/S0934-8840(98)80048-0

[29] Lindquist, L. (2008) Tick-Borne Encephalitis (TBE) in Childhood. Acta Paediatrica, 97, 532-534. http://dx.doi.org/10.1111/j.1651-2227.2008.00761.x

[30] Vene, S., et al. (1998) A Rapid Fluorescent Focus Inhibition Test for Detection of Neutralizing Antibodies to TickBorne Encephalitis Virus. Journal of Virological Methods, 73, 71-75. http://dx.doi.org/10.1016/S0166-0934(98)00041-X

[31] Mengelle, C., et al. (2004) Use of Two Real-Time Polymerase Chain Reactions (PCRs) to Detect Herpes Simplex Type 1 and 2-DNA after Automated Extraction of Nucleic Acid. Journal of Medical Virology, 74, 459-462. http://dx.doi.org/10.1002/jmv.20198

[32] Sauerbrei, A. and Wutzler, P. (2002) Laboratory Diagnosis of Central Nervous System Infections Caused by Herpesviruses. Journal of Clinical Virology, 25, S45-S51. http://dx.doi.org/10.1016/S1386-6532(02)00033-1

[33] Thoren, A. and Widell, A. (1994) PCR for the Diagnosis of Enteroviral Meningitis. Scandinavian Journal of Infectious Diseases, 26, 249-254. http://dx.doi.org/10.3109/00365549409011792

[34] Kanerva, M., et al. (2007) Search for Herpesviruses in Cerebrospinal Fluid of Facial Palsy Patients by PCR. Acta Otolaryngol, 127, 775-779. http://dx.doi.org/10.1080/00016480601011444

[35] Huttunen, P., et al. (2009) Differential Diagnosis of Acute Central Nervous System Infections in Children Using Modern Microbiological Methods. Acta Paediatrica, 98, 1300-1306. http://dx.doi.org/10.1111/j.1651-2227.2009.01336.x

[36] Tuerlinckx, D., et al. (2003) Clinical Data and Cerebrospinal Fluid Findings in Lyme Meningitis versus Aseptic Meningitis. European Journal of Pediatrics, 162, 150-153.

[37] Waespe, N., Steffen, I. and Heininger, U. (2010) Etiology of Aseptic Meningitis, Peripheral Facial Nerve Palsy, and a Combination of Both in Children. The Pediatric Infectious Disease Journal, 29, 453-456. http://dx.doi.org/10.1097/INF.0b013e3181c3cae6

\section{Abbreviations}

CNS: Central Nervous System

CSF: Cerebrospinal Fluid

DNA: Deoxyribonucleic Acid

ELISA: Enzyme Linked Immunosorbant Assay

EM: Erythema Migrans

HSV: Herpes Simplex Virus

iv: Intravenous

Ig: Immunoglobulin

LNB: Lyme Neuroborreliosis

PCR: Polymerase Chain Reaction

po: Peroral

RNA: Ribonucleic Acid

TBEV: Tick-Borne Encephalitis Virus

VZV: Varicella Zoster Virus 
Scientific Research Publishing (SCIRP) is one of the largest Open Access journal publishers. It is currently publishing more than 200 open access, online, peer-reviewed journals covering a wide range of academic disciplines. SCIRP serves the worldwide academic communities and contributes to the progress and application of science with its publication.

Other selected journals from SCIRP are listed as below. Submit your manuscript to us via either submit@scirp.org or Online Submission Portal.
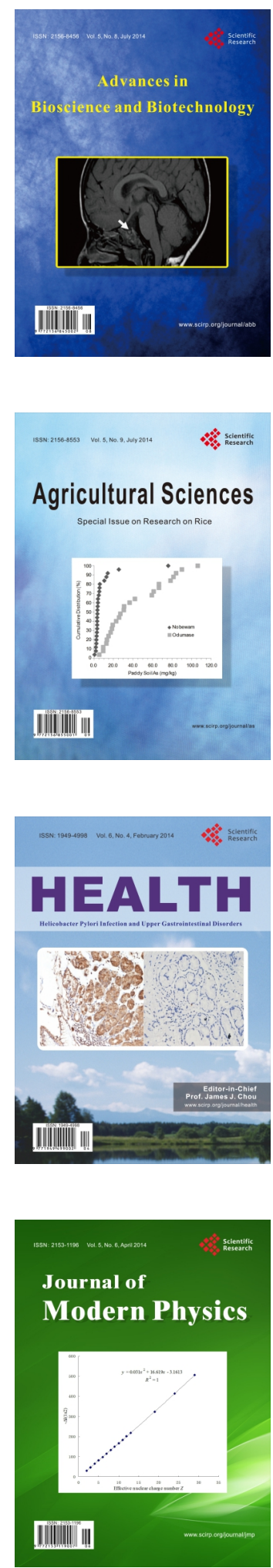
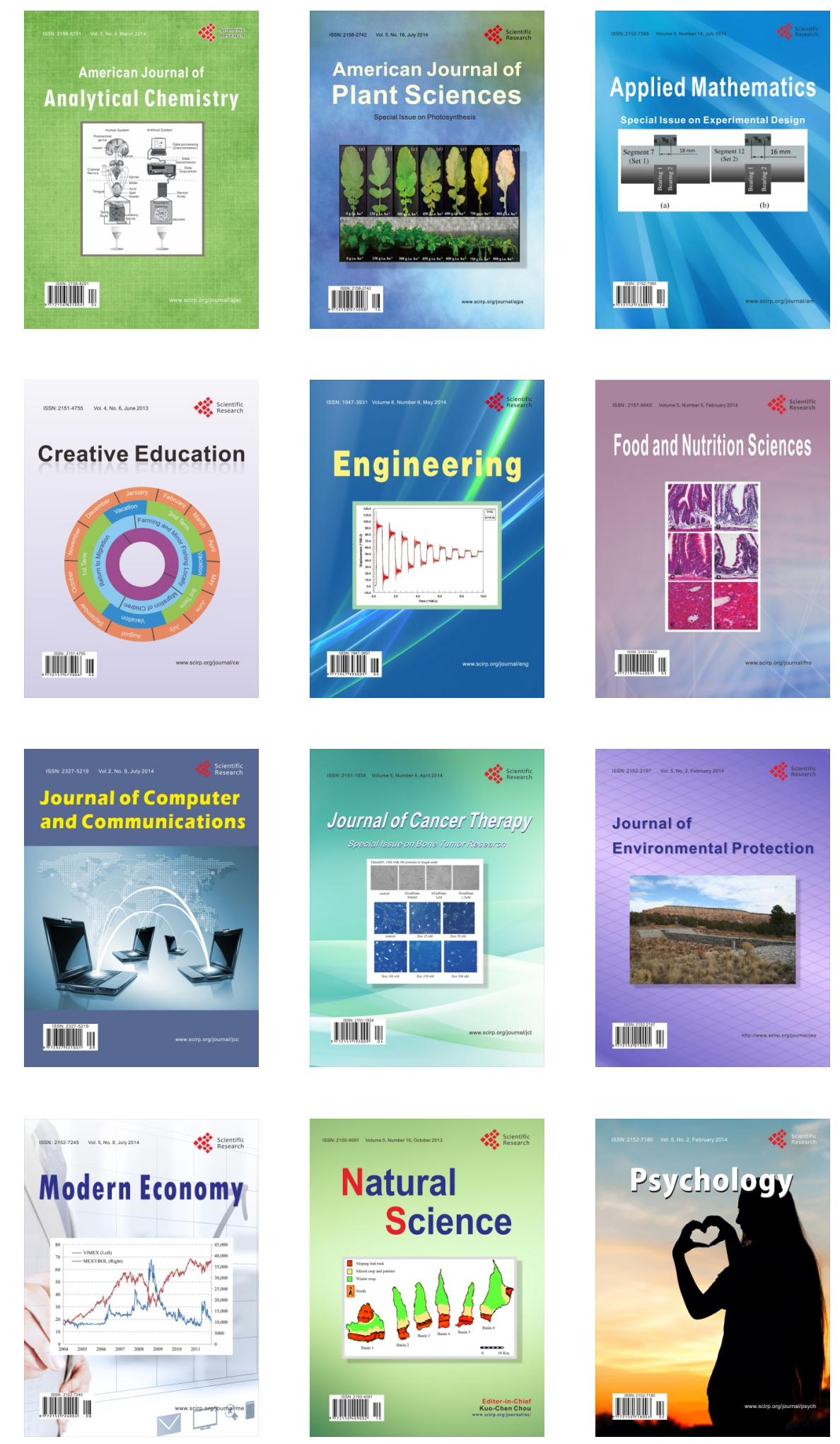